\title{
Lean Work and Gender Inequalities: Manufacturing Consent at a Multinational Car Plant in Provincial Russia
}

\author{
Martin Krzywdzinski, Grzegorz Lechowski, Valentina Mählmeyer \\ WZB Berlin Social Science Center, Germany
}

\begin{abstract}
How do local labour market structures, in tandem with workforce dispositions and attitudes, influence the way multinational companies localise their standardised work and production systems? This article investigates the conflict-ridden factory regime of a lean automotive plant in provincial Russia at which the management was able to secure a relatively high level of consent among its female workers but not among male workers. In order to explain this gendered pattern of worker consent, the plant-internal gender division of labour and two societal factors proved crucial: the gendered segmentation of the local labour market and the workers' cultural dispositions. At the same time, the analysis points to the transformative effect that the company's work and production system had on the local labour regime. The case study relies on a combination of quantitative survey data and qualitative interviews. It emphasises the need to reconnect the analysis of branch-plant factory regimes to a nuanced understanding of their embeddedness within local labour markets - also in the case of highly standardised work and production systems.
\end{abstract}

\section{KEY WORDS}

labour control regime; labour process; labour market; lean production; gender relations

\section{Introduction}

Leading multinational companies (MNCs) that relocate their production facilities to emerging countries may face specific difficulties in securing local worker consent. This is related, first, to various incompatibilities between the companies' standardised production systems and the placespecific societal conditions (see e.g. Boyer et al., 1998). In order to secure labour supply, the branch plants may feel forced to modify, or even abandon, some of their well-established organisational practices (Elger and Smith, 2005; Jürgens and Krzywdzinski, 2016). Second, these companies usually try to benefit from low wages and "permissive" labour regulations, which might lead to labour conflicts related to various "low-road" employment practices (Lüthje, 2014; Zhang, 2015; Barnes, 2017).

Our analysis adds to this debate on how multinationals secure worker consent in their emerging-market locations by analysing the case of RusCar, a lean automotive plant in provincial Russia, at which management-labour relations were particularly tense. As we will show, the management-labour conflicts were related to a set of local-societal factors underpinning the factory regime and had a clear gender dimension. From the very beginning, the factory's 
management encountered considerable problems with work discipline and organisational commitment. Most puzzling, however, was that the managers were able to secure a relatively high level of consent among the female employees. As one manager generalised about the gender difference in worker attitudes at the plant:

Here in Russia women are obviously the better workers. This is related to their interest in work, their engagement, their cooperative attitude (Quality Assurance Manager, September 2010).

In our empirical analysis, we will focus on reconstructing how the implementation of the company's standardised work and production system was influenced by the pre-existing gendered organisation of the local labour market. Our focus will thus lie on the role of local gender inequalities; we will only analyse other issues like the specific work culture, the skill formation systems or collective labour relations insofar as they have an impact on gender relations. Our analysis draws on concepts from labour process theory, which reconnect worker consent to external labour market structures (Elger and Smith, 2005; Smith, 2006), and in particular on recent analyses building on the notion of the "local labour control regimes" (Hastings and MacKinnon, 2016; Pattenden, 2016; Baglioni, 2017).

In addition, our study presents new empirical evidence about the influence of local gender inequalities on factory regimes. Research on gender-specific work attitudes and behaviour has increasingly emphasised the need for contextualised analyses that include the role of labour market conditions and institutions. Earlier studies of gender relations in MNCs in developing countries examined sweatshop factories and argued that their work and production systems often exploit local labour market segmentation and traditional gender identities (Lee, 1998; McKay, 2006; Ngai and Smith, 2007; Bank Muñoz, 2008). Our analysis, by contrast, focuses on the automotive industry, which usually provides relatively good work and employment conditions, including in emerging markets (Jürgens and Krzywdzinski, 2016). Furthermore, Russia differs from many developing and emerging countries in that women there have a less disadvantaged social position (Gerber and Mayorova, 2005), even if the inequalities between men and women are still significant, as indicated by the persistently large gender pay gap (Atenacio and Posadas, 2015). There is evidence in the sociological literature that the recent economic transformations have had various negative implications for men's labour market position in Russia (Ashwin and Lytkina, 2004). As some authors have suggested, Russian men found it more difficult than women to adapt to the new, "flexible" employment relations, particularly because of their traditional expectations of a stable work-based social status (Kiblitskaya, 2000; Ashwin, 2006; Kay, 2006).

We will rely on both qualitative material and quantitative data to describe the organisation of work at the plant, the worker attitudes and the situation in the local labour market. All the data was collected within two multiyear research projects. ${ }^{1}$

The remainder of the article is organised as follows. Beginning with a discussion of the relevant literature in section two, we will then discuss our research design and methods in detail in the third section. Section four presents the empirical analysis. First, we will reconstruct the general problems the company faced in implementing its work and production system at the

1 "Personnel and Production Systems in the BRICs" (2008-2012) conducted by Ulrich Jürgens and Martin Krzywdzinski, and "Performance Management Policies in International Comparison" (2012-2015) conducted by Martin Krzywdzinski and Valentina Mählmeyer. 
studied location; then we will focus on describing and explaining the gendered pattern of worker consent at the plant. The final section of the article presents our theoretical conclusions regarding the relationship between local social structures, multinationals' labour regimes and gender inequalities at the workplace level.

\section{Theoretical Framework}

\section{Local labour control regimes and worker agency}

The efforts of MNCs to implement their production and human resource management systems at foreign locations are a major research issue. Researchers have long observed that such efforts often end in "hybridisation" - that is, in a partial adaptation of the companies' organisational structures to the local societal conditions (Boyer et al., 1998). The existing literature has focused on two major factors influencing this process: first, the country-level institutional differences between the home and the host environment; and second, the strategies of the headquarters and branch-plant management teams (Kristensen and Zeitlin, 2004; Almond and Ferner, 2006; Jürgens and Krzywdzinski 2016). At the same time, the role of local labour in the hybridisation process has been rather neglected in the literature.

Worker agency and its impact on the implementation of managerial concepts has traditionally been the focus of labour process analysis (Thompson and O'Doherty, 2009). Many studies have shown that the organisation of work at multinational plants is not simply the result of "top-down" decisions by companies, but rather a product of ongoing bargaining and conflicts between the management and the workers. Elger and Smith (2005), for instance, reconstruct the complex "micropolitical processes" involved in adapting lean production at various Japanese transplants in Great Britain. In a more recent analysis, Rothstein (2016) explains the differences between the production systems at the Mexican and United States (US) plants of an American automotive company as being related to various strategies of local unions and, most importantly, to different levels of industrial experience among the local workforces.

In our analysis, we will build on this labour-process perspective on the "localisation" of multinational plants. At the same time, we will attempt to extend it by contributing a more indepth understanding of the influence of the social organisation of the local labour markets on both labour and managerial agency. Our starting points are recent discussions on the concept of the "local labour control regime" (LLCR) (Ellem, 2016; Hastings and MacKinnon, 2016; Pattenden, 2016), which emphasise the need to develop a place-sensitive analysis of labour processes and workplace regimes. The concept of the LLCR was coined by Andrew Jonas. It can be broadly defined as an institutionalised set of social mechanisms within a given local labour market through which workers are integrated into the sphere of production, and which, at the same time, co-ordinates their relation to the reproductive economy (Jonas, 1996, 2009). In the original formulation of the concept, the employers played the key role in organising the LLCRs (Ellem and Shields, 1999). The focus of the theory was on understanding how powerful companies operating in local contexts are able to extend their control over workers' behaviour by incorporating societal, and mostly informal, institutions into their work and employment regimes. More recent contributions emphasise labour agency. For instance, Hastings and MacKinnon (2016) show that the employees of various call centres in Scotland were able to reshape the 
workplace regimes according to their specific interests and social positions within the labour market.

\section{Gender and local labour control regimes}

Several studies suggest that gender is an important factor in the formation and functioning of LLCRs. One important contribution is Ching Kwan Lee's (1998) research on the electronics industry in South China. ${ }^{2}$ Her analysis draws attention to two societal factors contributing to female workers' high work discipline and engagement. First, there was the supply and demand structure in the local labour market, as well as its specific social organisation in the form of personal networks regulating access to available jobs. These networks narrowed female workers' job opportunities and increased their dependence on employment at the electronics plants. Second, there were the gender-specific dispositions internalised by the female workers in the domestic context - their family roles as submissive "maidens" or relatively assertive "matrons" which permeated the shop floor and shaped the women's attitudes at the point of production (see also: Bourdieu, 2005; McLeod, 2005). Finally, and similarly to the early LLCR theory, Lee emphasises that the managers, whose ideologies largely reflected local gender inequalities, organised the labour processes at the plants by exploiting the female workers' weak domestic and labour market positions.

Several other feminist studies have developed similar arguments. Fernández-Kelly's (1983) study of labour relations at assembly plants on the Mexican-American border, for instance, demonstrates how local female workers' docility was largely conditioned by their previous exclusion from the primary labour market. These findings fit well with Smith's (2006) concept of the "double indeterminacy of labour power", which emphasises that labour mobility strongly influences the organisation of the labour process.

The role of local labour market conditions, regulation and culture has been also discussed in the literature on job satisfaction and organisational commitment. While, for instance, in some countries there are hardly any gender differences in job satisfaction and organisational commitment (Marsden, Kalleberg and Cook, 1993), in other countries women show higher job satisfaction compared to men even if job characteristics regarding pay, working time, stress and security are controlled for (Roxburgh, 1999; Sousa-Poza and Sousa-Poza, 2000; Kaiser, 2007). The most convincing explanation of these differences relates to contextual factors, in particular discrimination and limited labour market access for women leading to lower expectations regarding job quality (Kaiser, 2007; Hauret and Williams, 2017).

At the same time, instead of simply reproducing women's disadvantaged social positions, work in multinational factories might offer local female workers a chance to depart from their traditional gender roles. Seen from this perspective, the high organisational commitment among female workers in multinational plants would not necessarily be an effect of extended patriarchal control, but rather an expression of individual agency (see also Bair, 2010). Marantz, Kalev and Lewin-Epstein (2014) illustrate how, by including local minority women into the workforce of two "globally themed" shopping centres, retailers transformed the pre-existing gender and ethnic segmentation of local labour. Lepadatu and Janoski's (2011) study of a Japanese car factory in the United States also shows clear differences in work behaviour and job satisfaction between men and women. The factory implemented very strict anti-discrimination policies, and women were

${ }^{2}$ For a similar perspective, see McKay (2006), Ngai and Smith (2007), Bank Muñoz (2008) and Mezzadri (2016). 
even regarded as more safety and quality conscious - an attitude highly valued by the Japanese management. Women showed a considerably higher job satisfaction than men, which Lepadatu and Janoski explain with reference to local labour market conditions. Working in a car factory offered women much higher pay than they could get in other jobs. In addition, it meant breaking out of traditional gender roles and generated a particular pride among the female employees.

\section{The Present Study: Research Design and Methods}

Our study focuses on the workplace regime at RusCar, a large and relatively new lean automotive plant established by a multinational car manufacturer in provincial Russia. In the empirical analysis, we will draw on the insights from both labour process theory and LLCR theory in order to explain why the plant's management was able to secure a relatively high consent among its female workers but not its male workers.

Building on the literature discussed above, we identify three interrelated dimensions of the micropolitical processes between the management and the workers that may account for the gendered pattern of consent at RusCar: (1) the organisation of the labour process by management, with particular attention to the gendered division of work; (2) the influence of external labour market opportunities on workers' consent; and (3) the role of the cultural dispositions imported to the plant by the workers.

As for the operationalisation of worker consent (the dependent variable of the analysis), we follow Hodson's (1999) suggestion to focus on two indicators: compliance and resistance behaviours. We focus on compliance with the basic rules of lean production systems (attendance, safety, standardised work, housekeeping) and on the conformity of workers with managerial demands regarding work performance and work behaviour. We understand worker resistance as including diverse forms of misbehaviour like absenteeism, quitting and accidents.

In order to analyse the gender differences in worker consent at RusCar, we relied on both qualitative and quantitative data. First, we used qualitative interviews to examine the difficulties the company faced when implementing its work and production system at the plant. Then, we turned to two sources of quantitative data in order to more precisely describe the gender differences in worker attitudes suggested by the managers. We used an employee survey on performance incentives and worker motivation that was conducted at the plant in April 2014 $(\mathrm{N}=1004$; see Table 1). Although the questionnaire included various items related to working conditions, in this analysis we only use the variables which were relevant to employees' workplace behaviour and their job satisfaction (see Table 7 in the annexure for descriptive statistics). The second source of quantitative data is the statistics provided by the company on gender differences relating to disciplinary dismissals and unexcused absences. As we will show, both data sources confirm the hypothesis of a gender difference in worker consent at RusCar.

In the next step of the analysis, we used qualitative data to explain the observed gender difference in worker consent by reconstructing the local labour control regime. Our primary data source here is ninety semi-structured interviews with managers, trade union representatives, bluecollar workers and white-collar employees (see Table 2). The variegated composition of the sample allows us to triangulate the perspectives on the workplace regime at the studied plant. The qualitative interviews dealt with a variety of topics related to the work and production system at RusCar, such as the standardisation of production, the human resources (HR) systems and the characteristics of performance management. In addition, the qualitative part of our analysis relies 
on the results of a two-month participant observation conducted by one of the authors at the plant - one month in the HR department and another month in the direct production area.

Table 1: The employee survey at RusCar

\begin{tabular}{|l|c|c|}
\hline & Returned questionnaires & Participation rate (\%) \\
\hline Men & 698 & 17.1 \\
\hline Women & 306 & 31.5 \\
\hline Total & 1004 & 19.9 \\
\hline
\end{tabular}

Data source: Kraywdrinski \& Mählmeyer (2015)

Table 2: Qualitative interviews at RusCar

\begin{tabular}{|l|c|c|c|}
\hline & \multicolumn{3}{|c|}{ Number of interviews } \\
\hline Respondent group & Men & Women & Total \\
\hline $\begin{array}{l}\text { HR and production } \\
\text { management }\end{array}$ & 42 & 8 & 50 \\
\hline Trade union & 6 & 2 & 8 \\
\hline Shop-floor supervisors & 9 & 1 & 10 \\
\hline Workers & 18 & 4 & 22 \\
\hline Total & 75 & 15 & 90 \\
\hline
\end{tabular}

Data source: Authors

\section{RusCar: Implementing Lean Work in Provincial Russia}

\section{General characteristics and history of the plant}

RusCar's parent company was one of the first foreign manufacturers to invest in the provincial region in central Russia where the studied plant was located. The factory was opened in the mid2000s, and in the following years several other multinational carmakers and suppliers developed facilities in the local industrial zones. While carmakers invest in Russia mainly for reasons of market access, they chose this specific location due to the low labour costs. The average wages at local industrial companies were about 50-60 per cent of what workers in Moscow or St. Petersburg earn. Moreover, the city in which the plant was situated has been a traditional location for the Russian defence and machine-building industries. For this reason, the foreign investors could expect a pool of well-qualified workers to be available in the local labour market.

During our data-collection period, RusCar underwent rapid development. The company had an ambitious goal of reaching full production capacity, with work on three shifts and four produced car models, within a relatively short period of time. During the first four years, the plant's workforce reached 5500 employees.

The work and production system implemented at the plant closely followed lean principles. The factory had minimal buffering between the manufacturing areas, and considerable emphasis was placed on team and standardised work. But the design of the plant was also lean in another 
sense: the parent company envisioned RusCar as a low-cost facility and therefore limited its investment in ergonomics and equipment. For example, the level of automation in the body shop was kept at 20 per cent - far below the level characteristic for the company's home country.

However, the rapid implementation of the lean production system at the plant soon turned out to be a great challenge. In the first years of the factory's operation, the discipline, productivity and quality problems were enormous. Labour turnover reached 40 per cent, absenteeism rates were high and many intense conflicts emerged on the shop floor. While the company needed to replace all the leaving workers smoothly, there was very little time and capacity to train the new recruits. The situation improved in later years, but the lack of worker consent remained the central problem for the plant's management.

Some problems with implementing the work and production system at RusCar were rooted in the company's generally unrealistic assessment of the local labour supply. In particular, management clearly overestimated the level of skills and industrial experience of the local workers. It soon became apparent that the basic introductory training offered by the company was not enough to prepare the workers for the requirements of lean work in an automobile factory. Due to budgetary constraints, it took the company several years to establish the necessary training programmes and infrastructure. Another factor which contributed to RusCar's problems was related to the low unemployment level in the area; according to the official statistics, this averaged about 4 per cent (Rosstat, 2011, 2013). This gave the local workers a strong bargaining position against the employer.

\section{Gender differences in worker consent at the plant}

One remarkable finding was that the problems with worker consent at the plant had a gender aspect. The managers often noted that female workers' attitudes corresponded well to the requirements of lean work - for instance, standardised work, safety rules, housekeeping and attendance - and that the lack of consent affected mostly the male employees. One of the quality engineers at the plant put it the following way:

We have had very good experiences with women.... Women have higher discipline and motivation than men. There is a significant difference. It is easier to work with women and they are more stable. ... And you don't have all these problems with alcohol, absenteeism, coming late to work (Quality Engineer, September 2010).

Similarly, the production director at the plant pointed specifically to problems with male workers' attitudes:

They [the male workers] don't have the discipline. You see it in the environment - you see the rubbish on the floor, you see they go for a picnic and they leave the rubbish because somebody will come behind and pick it up. $5 \mathrm{~S}$ is a basic principle of teamwork, $5 \mathrm{~S}$ in your area, you start and everything is clean and tidy. ${ }^{3}$ The Russians say, 'That's the job for the woman, it's not a man's job'. The thinking is that it's not a man's job to clean the floor or to sweep up (Production Manager, September 2010).

\footnotetext{
$35 \mathrm{~S}$ is a workplace organisation methodology in the lean production context. It refers to the Japanese terms seiri (sort), seiton (straighten), seiso (shine), seiketsu (standardise) and shitsuke (sustain).
} 
Based on our quantitative data, we were able to largely verify this managerial perception of the gender differences in worker behaviour at the plant. First, we analysed the data on two indicators of worker misbehaviour provided by the company: unexcused absences and disciplinary dismissals in the years 2013 and 2014. Regarding the absence rate, the findings were mixed. We did not find significant gender differences for the year 2013; but in 2014, men indeed had on average 0.7 absence days more than women. The difference is rather small, but we need to take into account that - as some interviewees indicated - it was more difficult for women to achieve even the same absence rates as men, since women were usually the ones who stayed at home for family emergencies (such as sick children). The second indicator - the individual disciplinary dismissals - provided a much clearer picture. As shown in Table 3, over 95 per cent of all the dismissals concerned male workers, while men's share of total employment in the plant was 81 per cent.

Table 3: Individual disciplinary dismissals at RusCar in 2013 and 2014

\begin{tabular}{|l|c|c|c|c|}
\hline & \multicolumn{2}{|c|}{ Men } & \multicolumn{2}{c|}{ Women } \\
\hline & Blue-collar & White-collar & Blue-collar & White-collar \\
\hline 2013 & $123(4.1 \%)$ & $6(0.5 \%)$ & $3(0.7 \%)$ & $1(0.2 \%)$ \\
\hline 2014 & $78(2.7 \%)$ & $6(0.4 \%)$ & $2(0.4 \%)$ & $0(0.0 \%)$ \\
\hline
\end{tabular}

Data source: the company. The percentages in brackets indicate the share of dismissals in the total number of employees of a given employee group.

In 2013 and 2014 (the years covered by this dataset), disciplinary dismissals were already much lower than they had been in the plant's first years when - according to our interview data 500 workers were laid off annually for disciplinary reasons. The data provided by the company also gives an insight into the reasons for the dismissals (see Figure 1). A quite striking feature here is the large number of cases related to one specific form of misbehaviour: alcohol consumption at work accounted for 6 per cent of all dismissals. But importantly, as we learned from the HR department, many dismissals classified as belonging to other categories were, in fact, also related to alcohol consumption. The large scale of alcohol-related misbehaviour at the plant may be explained by a specific male drinking culture in Russia - a point to which we will return later.

The second data source we used to verify the managerial perception of gender differences in worker consent was the employee survey. This allowed us to check the differences between male and female workers regarding extra-role behaviour - that is, employees' engagement beyond the narrowly specified job tasks. Extra-role behaviour is often metaphorically described as "walking the extra mile" (Gould-Williams, 2003). It includes supporting colleagues, willingness to do overtime work, volunteering or seeking additional training opportunities (Gould-Williams, 2003; Knies and Leisink, 2014). Table 4 shows the influence of gender on employees' self-described extra-role behaviour - with the odds ratios describing the probability of women giving a positive answer to one of the listed questions in comparison to men. Because the data describe workers' subjective assessments of their own behaviour, we have to be cautious when interpreting them. Yet, bearing this reservation in mind, the analysis suggests some clear gender differences. On nearly all the items, women describe their work behaviour more positively than men - even 
though, admittedly, not all coefficients are significant. Yet the following differences were statistically significant: first, taking university courses after work and second - and most markedly - speaking to colleagues who come late or work sloppily. The latter probability is 1.79 times higher among women than men.

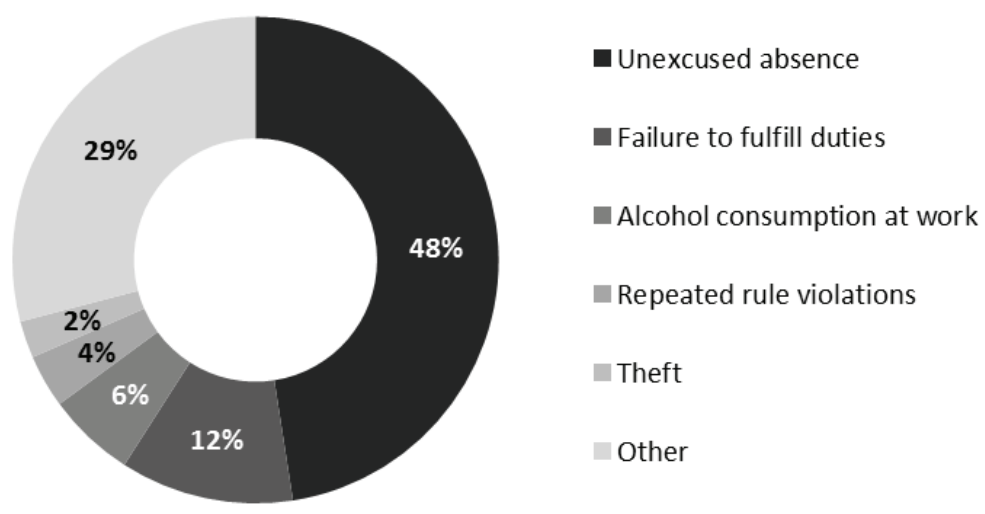

Source: Authors, based on company data.

Figure 1: Reasons for individual disciplinary dismissals at RusCar, 2013

Table 4: Influence of gender on extra-role behaviour (women compared to men, ordered logistic regression)

\begin{tabular}{|c|c|c|c|}
\hline & Odds ratio & Std. error & $\mathbf{N}$ \\
\hline $\begin{array}{l}\text { If someone comes late to work or works sloppily, I } \\
\text { will speak to him/her about it. }\end{array}$ & $1.79 * * *$ & 0.29 & 876 \\
\hline $\begin{array}{l}\text { I am taking a university course in my spare time to } \\
\text { have better chances to develop my career within the } \\
\text { company. }\end{array}$ & $1.32^{*}$ & 0.19 & 874 \\
\hline $\begin{array}{l}\text { If I see colleagues who have forgotten their safety } \\
\text { gear, I will tell them. }\end{array}$ & 1.29 & 0.20 & 870 \\
\hline $\begin{array}{l}\text { I strive to create a good atmosphere in the team and } \\
\text { organise meet-ups or activities like barbecues or } \\
\text { parties, }\end{array}$ & 1.24 & 0.19 & 879 \\
\hline $\begin{array}{l}\text { After work, I often think about how I could develop } \\
\text { improvement proposals for work processes in my } \\
\text { area. }\end{array}$ & 1.16 & 0.17 & 875 \\
\hline $\begin{array}{l}\text { I defend my colleagues against unfair treatment, even } \\
\text { in front of the supervisor. }\end{array}$ & 1.09 & 0.19 & 879 \\
\hline $\begin{array}{l}\text { I often volunteer to help and support new colleagues } \\
\text { to get started at their job. }\end{array}$ & 1.09 & 0.21 & 879 \\
\hline $\begin{array}{l}\text { I defend my company if someone from my circle of } \\
\text { friends criticises it. }\end{array}$ & $0.53^{* * *}$ & 0.08 & 879 \\
\hline
\end{tabular}

Controls for age, job tenure, educational attainment, hierarchy level, area/ department of work. Weighted data. * 0.10, ** 0.05, ***0.01. Data source: Kraywdzinski and Mählmeyer (2015)

At the same time, as Table 4 shows, the gender differences are not always clear-cut. For 
instance, men seemed to identify more strongly with the company, as they expressed a greater readiness to defend it against criticism in non-work contexts. One possible explanation for this difference is the traditionally "work-centric" notion of self-identity among Russian men (Ashwin and Lytkina, 2004). But at the same time, the more limited willingness to defend the company exhibited by female workers at RusCar may be related to their lower level of job satisfaction, as described in Table 5. One remarkable aspect is that this lower job satisfaction did not undermine the organisational commitment and work discipline among the female workers.

Table 5: Influence of gender on job satisfaction at RusCar (female compared to male employees, ordered logistic regression)

\begin{tabular}{|l|c|c|c|}
\hline & Odds ratio & Std. error & N \\
\hline In general, I'm satisfied with the work at the company. & $0.53^{* * *}$ & 0.09 & 898 \\
\hline
\end{tabular}

Controls for age, job tenure, educational attainment, bierarchy level, areal department of work. Weighted data. * $0.10, * * 0.05$, *** 0.01. Data source: Krayydzzinski and Mäblmeyer (2015)

In sum, based on our quantitative data we were able to largely confirm the managerial perceptions of gender differences in worker consent at RusCar. Some differences, like those in attendance, proved smaller than could have been expected based on the managers' rather dramatic descriptions of male workers' misbehaviour; others, like the disciplinary dismissals and the extra-role behaviour, were indeed very high.

In the following subsections, we will reconstruct the major elements of the local labour control regime that may account for this observed gender difference in worker consent.

\section{Gendered division of labour at the plant}

Given management's explicit praise for the local female workers, one could expect women to have good career opportunities at the plant. And given that RusCar's official policy was to avoid gender discrimination, the assignment of women to specific jobs at the plant should have been limited only by the country-level legal restrictions regarding, for instance, the maximum lifting weight allowable for women (Kozina and Zhidkova, 2006). Indeed, there is some truth to this: the share of women in shop-floor employment was significant - and, in fact, it was higher than at some typical Western European car plants (Moore, 2015). At the same time, however, RusCar developed a clearly gender-biased division of labour, which corresponded to stereotypical assumptions regarding male- and female-specific skills and reproduced patterns typical for Russian companies (Maltseva and Nesterova, 2012).

Production at the factory was organised into three shops, and the gendered structure was clearly visible within them. First, there was the almost completely male welding shop. Due to the company's low-investment approach, the welding process was not very automated and the main type of work done here was manual point welding with heavy welding guns. The management relied on the traditional acceptance of hard physical work by the male workers to compensate for the low-cost design of the plant.

Another important characteristic of the body shop was the significant tensions between management and the workers regarding compliance with standardised work. Under the difficult working conditions, the workers were always looking for ways to speed up their work by ignoring certain rules and creating time for informal small breaks. Importantly, even such small deviations 
from the prescribed welding procedure could impair the stability of the produced car bodies. For this reason, management was very strict in monitoring and enforcing the work standards here which turned the welding shop into a hotspot for conflicts.

In contrast, two other shops had a significant share of female workers. At the paint shop, around 30 per cent of the workers were women, employed mainly in the pre-paint cleaning and sealing of the car bodies. These jobs were regarded by management as "female" because they required high manual dexterity and precision. The situation was similar at the assembly shop, with the share of female workers at around 10-15 per cent. When explaining this gendered division of labour in the manual production areas, a section manager mentioned female workers' perceived "natural" abilities:

\begin{abstract}
Women are women, at home and at work. You cannot treat women and men in the same way. There are areas and work stations that are too difficult for women. In our section, women mainly work with the doors. They are very orderly. They have nimble hands and can fix the rubber seal very nicely. In the chassis assembly, you have to handle heavy tools and this is not appropriate for women. We try to assign women to areas where they can make use of their qualities (Section Manager, September 2010).
\end{abstract}

Importantly, the gender segregation at the plant also had a vertical dimension. Due to the country-level regulations restricting female employment in areas with heavy lifting, women often could not fully participate in the job rotation in their teams. And because of this, supervisors seeing only limited benefits from female workers' additional skills - tended to exclude them from further training. In general, in order to gain promotion to team leader (and later to supervisor), employees were required to master most tasks in their respective teams (or areas). Thus, the limited participation in job rotation and training reduced career opportunities for women in the production areas.

\title{
Workers' labour market opportunities
}

In our interviews, several female employees emphasised that it would be very difficult for them to find alternative well-paid jobs locally if they were laid off. This, as the interviewees pointed out, was related to the fact that the "good" jobs in the local arms and machine-building factories were mostly available to male workers, whereas women were typically employed in the local service sector. In addition, there were various relatively well-paid self-employment options (such as taxi driving) available locally for men but not for women. As one of the female workers described the situation:

It is difficult for women to find good jobs. All the state companies in our region went bankrupt. What options do we have? Only working in retail. That's why women like working at RusCar. For men, it is easier to find an equivalent job. They can work in transport companies, as taxi drivers or in many other companies. They always find something good (Female worker, September 2010).

Another female respondent, who worked in a white-collar area at RusCar, described the hiring practices of the local companies, which - according to her - discriminated against women:

The salary at RusCar is much more attractive than in the Russian companies. In particular for women, it is not easy to find a well-paid job. Usually, companies hire men for the better jobs and 
higher positions (Female white-collar employee, September 2010).

These perceptions of the pre-existing gender inequalities in the local labour market are generally confirmed by macro-statistical data. As shown in Table 6, the regional wage inequalities between men and women were significant, with the gender pay gap at about 38 per cent. These perceptions also correspond to the existing country-level descriptions of the persistent wage discrepancies between men and women in the Russian labour market (Gerber and Mayorova, 2005; Atencio and Posadas, 2015).

Table 6: Gender inequalities in the local labour market

\begin{tabular}{|c|c|c|}
\hline & Women & Men \\
\hline Average monthly wage (2011) & $\begin{array}{c}\text { 16,500 RUB } \\
\text { (265 EUR) }\end{array}$ & $\begin{array}{c}26,900 \text { RUB } \\
\text { (440 EUR) }\end{array}$ \\
\hline Labour force participation rate* (2011) & $64 \%$ & $76 \%$ \\
\hline Unemployment rate* (2013) & $5.2 \%$ & $4.4 \%$ \\
\hline
\end{tabular}

Given the large gender pay gap in the local labour market, it was generally not surprising that many female employees perceived their earnings at RusCar as "high". But at the same time, the greater readiness among women employed at the plant to accept the de facto relatively low wages may be explained by the traditional family structures in which their labour market activity was embedded. As observed in the existing literature, persistent in Russian society is a specific division of male and female family roles - with men as full-time "breadwinners" and women often involved in the "double shift" of "secondary" formal employment and domestic responsibilities (Ashwin, 2006; Kay, 2006). Indeed, one of our female interviewees justified her satisfaction with the pay level at RusCar as follows:

I know that manual workers earn very little. Men used to get something like 13000 or 14000 rubles net. Now they've increased the wages to about 17000 rubles, but for men it is still not enough. ... For women, 17000 is a good wage, but for men it is not very much. As you know, men have to earn enough to keep a family (Female white-collar employee, September 2010).

Furthermore, according to our field notes, many of the female workers at the plant were single or divorced parents. In general, the high proportion of divorced mothers in the workforce is characteristic for the Russian labour market (UNStats, 2018). Moreover, some of the divorced female employees at RusCar were reportedly not receiving any maintenance from their former partners. These women were, therefore, highly motivated to keep their jobs at RusCar in order to ensure the highest possible income for their families.

\section{Workers' cultural dispositions}

Another factor contributing to the gender difference in consent at the plant are the male- and female-specific dispositions internalised beyond the workplace. Our material indicates that the gendered behavioural patterns fit into the company's work culture in different and often uneasy 
ways.

On the one hand, many dispositions brought into the plant by the female workers corresponded well to RusCar's work and production model. Numerous supervisors, but also female workers themselves, emphasised the habitus of responsibility, flexibility and patience with standardised work which was said to be based in female-specific social practices beyond the workplace. For instance, many female interviewees pointed out that during the crisis in the 1990s, it was women who largely took responsibility for the well-being of their families, and argued that these experiences made them internalise a particularly high flexibility and work discipline. This perception was largely confirmed in various statements by the managers. One of the interviewed supervisors used a recent assessment-centre procedure at the plant as an example of the specific habitus imported to the plant by the female workers:

We sent twelve candidates in our section to the team leader assessment. I think that three of them were men, the rest women. ... No man got through the assessment, while five women passed the evaluation. ... I think that Russian women are used to doing everything for themselves. They are responsible for the kids, they are responsible for the work (Quality Engineer, September 2010).

There was also another dimension of the female workplace habitus which rendered the image of the "ideal" - that is, "flexible" and "responsible" - female worker problematic, and which, surprisingly, received little attention in managers' narratives. Many women at the plant invested a lot of effort in displaying their femininity through clothing or makeup. Despite the explicit ban on wearing rings, watches or necklaces on the assembly line, many female employees decided to keep their jewellery on at work. These rule violations were partially tolerated by the managers.

On the other hand, our material points to various male-specific dispositions that were overtly rejected by the management. First, the managers were very critical of the work practices that men with previous factory experience had learned in local firms. Reportedly, the male workers paid little attention to workplace cleanliness and housekeeping, which was seen by management as essential for the lean production system. When explaining why they refused to keep the workplace clean, the workers often responded that it was normal that "male" workstations were dirty and that the cleaning was a "female" job. Second, many male employees displayed various counterproductive behaviours at work which, according to the managers, were part of the local "macho culture". For instance, the men often deliberately avoided using manipulators or safety equipment in order to demonstrate their physical strength.

Several of our interviewees explained these behaviour patterns with reference to the socialisation of young men during the 1990s. One trade union representative emphasised that young Russians in the 1990s were raised in chaotic circumstances and that their fathers had often failed to be role models for the children. He explained that this had considerable consequences for their work behaviour:

We have many really difficult people on the shop floor. They were kids in the 1990s when our whole society in Russia broke down. Under those conditions, they did not really get a good upbringing. You see that they are very rough people with sometimes awful behaviour. One of my teammates often boasted about how he steals stuff at the supermarket. And he was the father of a family! ... Many of our workers just throw garbage, scraps and other stuff on the floor. I spend a lot of time trying to change their habits (Trade union representative, April 2014). 
And finally, there was the problem of alcohol-related misbehaviour among the male workers. Although the issue was emphasised by numerous interviewed managers, the company's official statistics only partly reflected the scale of the problem. This, according to the managers, was due to the fact that, even if caught drunk at work, employees were often able to cheat the official tests by bribing the local doctors. In general, alcohol-related misbehaviour might be seen as a part of the traditional Russian - and Soviet - culture of male heavy drinking (Bobrova et al., 2010; Hinote and Webber, 2012). And recent research suggests that the problem became even more widespread in the context of post-socialist transformation, affecting largely the workingclass men (Carlson and Vagero, 1998; Carlson, 2008).

\section{Discussion and Conclusions}

Our analysis investigated how local-societal factors influenced the implementation of a lean work regime and, in particular, the gendered pattern of worker consent at RusCar, a multinational automotive plant in provincial Russia. We attempted to explain how the company has managed to secure a relatively high level of consent among its female workers, but at the same time faced significant problems in integrating the male workers into its production system.

Our major finding is that while the general problems with worker consent at the plant were at least partially linked to RusCar's low-cost orientation - which resulted in under-investment in skill formation and a low wage level - the differences between the male and female workforce's work behaviour were related to a combination of workplace-internal factors and the local labour market conditions.

The major workplace-internal factor contributing to the gender difference in worker consent at RusCar was the division of labour at the plant. Male workers were assigned to the most physically demanding tasks and, largely for this reason, conflicts between them and the managers were relatively common. By contrast, women at RusCar were mainly employed in less physically demanding positions and were often excluded from full job rotation and advancement opportunities.

The local labour-market demand structure - which can be seen as one element of the LLCR - strongly motivated female workers to retain their jobs at the plant. Although the career opportunities for women employed on the shop floor were limited, the company was nevertheless offering them a "good enough" alternative to the typical "female" jobs available locally - for instance, to the employment in the local retail sector. Female workers often wanted to keep their relatively low-paid jobs at RusCar because of their specific household positions as either "supplementary earners" or single parents. Male workers, on the contrary, had more relatively well-paid job opportunities available to them locally, which made them much less dependent on their employment at the plant.

The second element of the LLCR was the gender-specific behavioural dispositions brought to the plant by the workers. In general, the forms of behaviour imported by the men - for instance, their lack of concern for cleanliness standards and their drinking habits - were seen by the management as incompatible with the company's lean work and production system. Women, on the contrary, demonstrated more commitment and discipline.

Besides pointing to the general mechanisms shaping the gendered pattern of consent in the workplace, our study reconstructs the specific form in which these mechanisms worked in the 
studied Russian case. Regarding labour market conditions, it points to the impact of the gender pay gap on differences in work behaviour between men and women, while studies on Malaysia (McKay, 2006) or Mexico (Bank Muñoz, 2008) more strongly emphasise the rigid gender segregation regarding access to jobs and job opportunities. As far as cultural dispositions are concerned, the particularities of the Russian context are even more pronounced. In contrast to the Chinese dagongmei (Ngai, 2004) or the female workers in the Mexican maquiladoras described by Salzinger (1997), the women in our study cannot be simply characterised as a "docile workforce". They have rather demonstrated a habitus of "ultra-flexibility" and "responsibility" observed also in previous studies on Russian post-socialist gender relations. At the same time, the observed male working-class habitus was related to such forms of misbehaviour as breaking safety rules or, in general, "doing what you want when you want" (e.g. smoking breaks, coming late, alcohol consumption).

Regarding the organisation of work at the plant, and despite official regulations and some attempts of the RusCar management to implement gender-neutral recruitment and promotion policies, the plant largely reproduced gendered divisions of labour and hierarchy structures based on traditional concepts that were also observed in other workplace regimes in Russia (Maltseva and Nesterova, 2012).

In sum, our study shows how the research on workplace behaviour and worker attitudes at multinational plants can benefit from taking into account the local-societal and local labour market conditions, as was generally suggested by the LLCR approach. For one thing, we have demonstrated that the male and female workers' willingness to comply with the employer's performance expectations was generally conditioned by their perceived labour market opportunities and their cultural dispositions internalised beyond the workplace. Women showed high work discipline and commitment despite being less satisfied with the work in the car factory than men. This finding also supports the arguments that the relationship between the objective working and employment conditions on the one hand and job satisfaction and commitment on the other is mediated by contextual factors (Kaiser, 2007; Vidal, 2007; Brown, Charlwood and Spencer, 2012).

At the same time, however, the studied case complements the existing conceptualisations of the influence of external social and labour market structures on workplace regimes from the LLCR perspective in three important respects.

First, the observed problems with male workers' attitudes demonstrate the limits imposed on managerial agency by local social and labour market structures. Many earlier studies focusing on female factory work in the Global South - for instance Lee (1998), McKay (2006) or Bank Muñoz (2008) - have emphasised how management strategically incorporated the local gender inequalities into the workplace regimes. Our case company, RusCar, has not developed this kind of control strategy. In fact, the gender relations in the studied factory interacted with the company's production system in a rather dysfunctional way. The power of management over the male workers was limited due to the latter's external labour market mobility (Smith, 2006). On top of this, the cultural dispositions brought to the plant by the male workers proved largely incompatible with the requirements of the highly standardised regime of lean production. And while the female workers' attitudes were regarded by the managers as "ideal" for the company's production system, management was not ready to abandon its stereotypical conceptions of "appropriate" work for men and women. This persistent disjunction between the local structural conditions and the company's employment strategy suggests that learning how to adapt to a 
foreign location is often a difficult and lengthy process in the case of multinational plants.

Second, our results bring to the fore the diversity of labour agency within a given workplace regime. In the studied case, the "micropolitics of hybridisation" (Elger and Smith, 2005) were shaped not simply by interactions between management and the local workers (Hastings and MacKinnon, 2016), but rather also by the differential social positions of the company's male and female employees.

Third, our study suggests that the company's relatively gender-inclusive employment strategy had a transformative effect on the position of women in the local labour market. Although the career opportunities for the female workers on the shop floor were limited, the company was nevertheless offering them a reasonable alternative to the typical local "female" jobs. In this way, the opening of the large multinational automotive plant seems to have reshaped local women's employment opportunities.

\section{REFERENCES}

Almond, P. and A. Ferner (2006) American Multinationals in Europe: Managing Employment Relations across National Borders. Oxford: Oxford University Press.

Ashwin, S. (2006) Dealing with Devastation in Russia: Men and Women Compared. In Adapting to Russia's New Labor Market, edited by S. Ashwin. Abingdon and New York: Routledge.

Ashwin, S. and T. Lytkina (2004) Men in Crisis in Russia: The Role of Domestic Marginalization. Gender \& Society, 18(2): 189-206.

Atencio, A. and J. Posadas (2015) Gender Gap in Pay in the Russian Federation: Twenty Years Later, Still a Concern. Washington, DC: World Bank.

Baglioni, E. (2018). Labour Control and the Labour Question in Global Production Networks: Exploitation and Disciplining in Senegalese Export Horticulture. Journal of Economic Geography, 18(1): 111-137.

Bair, J. (2010) On Difference and Capital. Gender and the Globalization of Production. Signs, 36(1): 203226.

Bank Muñoz, C. (2008) Transnational Tortillas: Race, Gender, and Shop-floor Politics in Mexico and the United States. Ithaca, NY: ILR Press.

Barnes, T. (2017) Why has the Indian Automotive Industry Reproduced "Low Road" Labour Relations? In Critical Perspectives on Work and Employment in Globalizing India, edited by E. Noronha and P. D'Cruz. Mumbai: Springer.

Bobrova, N., R. West, D. Malyutina, S. Malyutina and M. Bobak (2010) Gender Differences in Drinking Practices in Middle Aged and Older Russians. Alcohol and Alcoholism, 45(6): 573-580.

Bourdieu, P. (2005) Principles of an Economic Anthropology. In The Handbook of Economic Sociology, edited by N.J. Smelser and R. Swedberg. Princeton, NJ: Princeton University Press.

Boyer, R., E. Charron, U. Jürgens and S. Tolliday (Eds.) (1998) Between Imitation and Innovation: The Transfer and Hybridization of Productive Models in the International Automobile Industry. Oxford: Oxford University Press.

Brown, A., A. Charlwood and D. Spencer (2012) Not All that it Might Seem: Why Job Satisfaction is Worth Studying despite it being a Poor Summary Measure of Job Quality. Work, Employment \& Society, 26(6), 1007-1018. 
Carlson, P. (2008) Commentary: Russia's Mortality Crisis, Alcohol and Social Transformation. International Journal of Epidemiology, 38(1): 156-157.

Carlson, P. and D. Vagero (1998) The Social Pattern of Heavy Drinking in Russia during Transition: Evidence from Taganrog 1993. The European Journal of Public Health, 8(4): 280-285.

Elger, T. and C. Smith (2005) Assembling Work: Remaking Factory Regimes in Japanese Multinationals in Britain. Oxford: Oxford University Press.

Ellem, B. (2016) Geographies of the Labour Process: Automation and the Spatiality of Mining. Work, Employment and Society, 30(6), 932-948.

Ellem, B. and J. Shields (1999) Rethinking "Regional Industrial Relations": Space, Place and the Social Relations of Work. Journal of Industrial Relations, 41(4): 536-560.

Fernández-Kelly, M.P. (1983). For We Are Sold, I and My People. Women and Industry in Mexico's Frontier. Albany, NY: State University of New York Press.

Gerber, T.P. and O. Mayorova (2005) Dynamic Gender Differences in a Post-socialist Labor Market: Russia, 1991-1997. Social Forces, 84(4): 2047-2075.

Gould-Williams, J. (2003) The Importance of HR Practices and Workplace Trust in Achieving Superior Performance: A Study of Public-sector Organizations. International Journal of Human Resource Management, 14(1), 28-54.

Hastings, T. and D. MacKinnon (2016) Re-embedding Agency at the Workplace Scale: Workers and Labour Control in Glasgow Call Centres. Environment and Planning A, 49(1): 104-120.

Hauret, L. and D. Williams (2017) Cross-National Analysis of Gender Differences in Job Satisfaction. Industrial Relations, 56(2): 203-235.

Hinote, B.P. and G..R. Webber (2012) Drinking toward Manhood: Masculinity and Alcohol in the Former USSR. Men and Masculinities, 15(3): 292-310.

Hodson, R. (1999) Organizational Anomie and Worker Consent. Work and Occupations, 26(3): 292-323.

Jonas, A.E.G. (1996) Local Labour Control Regimes: Uneven Development and the Social Regulation of Production. Regional Studies, 30(4): 323-338.

Jonas, A.E.G. (2009) Labor Control Regime. In International Encyclopedia of Human Geography, edited by N. Thrift. Oxford: Elsevier.

Jürgens, U. and M. Krzywdzinski (2016) New Worlds of Work. Varieties of Work in Car Factories in the BRIC Countries. Oxford: Oxford University Press.

Kaiser, L. (2007) Gender-Job Satisfaction Differences across Europe. International Journal of Manpower, 28(1): 75-94.

Kay, R. (2006) Men in Contemporary Russia: The Fallen Heroes of Post-Soviet Change. Aldershot: Ashgate.

Kiblitskaya, M. (2000) Once We Were Kings: Male Experiences of Loss of Status at Work in Postcommunist Russia. In Gender, State and Society in Soviet and Post-Soviet Russia, edited by S. Ashwin. London: Routledge.

Knies, E. and P. Leisink (2014) Linking People Management and Extra-role Behaviour: Results of a Longitudinal Study. Human Resource Management Journal, 24(1): 57-76.

Kozina, I. and E. Zhidkova (2006) Sex Segregation and Discrimination in the New Russian Labour Market. In Adapting to Russia's New Labour Market. Gender and Employment Bebaviour, edited by S. Ashwin. Abingdon/New York: Routledge.

Kristensen, P.H. and J. Zeitlin (2004) Local Players in Global Games: The Strategic Constitution of a Multinational Corporation. Oxford: Oxford University Press.

Krzywdzinski, M. and V. Mählmeyer (2015) Performance Management Policies in International 
Comparison. Case Studies and Interviews, Version 1.0.0. Berlin: WZB (unpublished data set).

Lee, C.K. (1998) Gender and the South China Miracle: Two Worlds of Factory Women. Berkeley, CA: University of California Press.

Lepadatu, D. and T. Janoski (2011) Diversity at Kaizen Motors. Lanham, MD: University of America Press.

Lüthje, B. (2014) Labour Relations, Production Regimes and Labour Conflicts in the Chinese Automotive Industry. International Labour Review, 153(4): 535-560.

Maltseva, I. and D. Nesterova (2012) Gender Segregation within Firms: Causes and Consequences. In In the Grip of Transition: Economic and Social Consequences of Restructuring in Russia and Ukraine, edited by T. Bruk and H. Lehmann. London: Palgrave Macmillan.

Marantz, E.A., A. Kalev and N. Lewin-Epstein (2014) Globally Themed Organizations as Labor Market Intermediaries: The Rise of Israeli-Palestinian Women's Employment in Retail. Social Forces, 93(2): 595-622.

Marsden, P., A. Kalleberg and C. Cook (1993) Gender Differences in Organizational Commitment. Work and Occupations, 20(3): 368-390.

McKay, S.C. (2006) Satanic Mills or Silicon Islands?: The Politics of High-tech Production in the Philippines. Ithaca, NY: Cornell University Press.

McLeod, J. (2005) Feminists Re-reading Bourdieu: Old Debates and New Questions about Gender Habitus and Gender Change. Theory and Research in Education, 3(1): 11-30.

Mezzadri, A. (2016) Class, Gender and the Sweatshop: On the Nexus between Labour Commodification and Exploitation. Third World Quarterly, 37(10): 1877-1900.

Moore, F. (2015) An Unsuitable Job for a Woman: A “Native Category” Approach to Gender, Diversity and Cross-cultural Management. The International Journal of Human Resource Management, 26(2): 216-230.

Ngai, P. (2004) Women Workers and Precarious Employment in Shenzhen Special Economic Zone, China. Gender and Development, 12(2): 29-36.

Ngai, P. and C. Smith (2007) Putting Transnational Labour Process in its Place: The Dormitory Labour Regime in Post-socialist China. Work, Employment and Society, 21(1): 27-45.

Pattenden, J. (2016) Working at the Margins of Global Production Networks: Local Labour Control Regimes and Rural-based Labourers in South India. Third World Quarterly, 37(10): 1809-1833.

Rosstat (2011) Regiony Rossii. Social'no-èkonomičeskie pokazateli. Moscow: Russian Federal State Statistics Service.

Rosstat (2013) Regiony Rossii. Social'no-èkonomičeskie pokazateli. Moscow: Russian Federal State Statistics Service.

Rothstein, J.S. (2016) Contextualizing Work: The Influence of Workplace History and Perceptions of the Future on Lean Production at Three GM Plants. Critical Sociology, 42(7-8): 1143-1161.

Roxburgh, S. (1999) Exploring the Work and Family Relationship. Journal of Family Issues, 20(6): 771-788.

Salzinger, L. (1997) From High Heels to Swathed Bodies: Gendered Meanings under Production in Mexico's Export-processing Industry. Feminist Studies 23(3): 549-574.

Smith, C. (2006) The Double Indeterminacy of Labour Power: Labour Effort and Labour Mobility. Work, Employment and Society, 20(2): 389-402.

Sousa-Poza, A. and A..A. Sousa-Poza (2000) Taking Another Look at the Gender/Job-Satisfaction Paradox. Kyklos, 53(2): 135-152.

Thompson, P. and D.P. O’Doherty (2009) Perspectives on Labor Process Theory. In The Oxford Handbook of Critical Management Studies, edited by M. Alvesson, T. Bridgman and H. Willmot. Oxford: Oxford University Press. 
UNStats (2018) United Nations Demographics Yearbook 2017. New York: United Nations.

Vidal, M. (2007) Lean Production, Worker Empowerment, and Job Satisfaction: A Qualitative Analysis and Critique. Critical Sociology, 33(1-2): 247-278.

Zhang, L. (2015) Inside China's Automobile Factories. New York: Cambridge University Press.

\section{BIOGRAPHICAL NOTES}

MARTIN KRZYWDZINSKI is head of the research group "Globalization, Work and Production" at the WZB Berlin Social Science Center, and Director at the Weizenbaum Institute for the Networked Society. [Email: martin.krzywdzinski@,wzb.eu]

GRZEGORZ LECHOWSKI is researcher at the research group "Globalization, Work and Production” at the WZB Berlin Social Science Center. [Email: grzegorz.lechowski@wzb.eu]

VALENTINA MÄHLMEYER is researcher at the research group "Globalization, Work and Production” at the WZB Berlin Social Science Center. [Email: valentina.maehlmeyer@wzb.eu]

\section{ANNEXURE}

Table 7: Descriptive statistics and selected variables from the RusCar survey

\begin{tabular}{|c|c|c|c|c|c|}
\hline & Mean & Std. dev. & Min & $\operatorname{Max}$ & $\mathrm{N}$ \\
\hline $\begin{array}{l}\text { In general, I'm satisfied with the work at the } \\
\text { company. }\end{array}$ & 1.85 & 0.77 & 1 & 4 & 993 \\
\hline $\begin{array}{l}\text { If someone comes late to work or works } \\
\text { sloppily, I will speak to him/her about it. }\end{array}$ & 2.36 & 0.97 & 1 & 4 & 968 \\
\hline $\begin{array}{l}\text { I am taking a university course in my spare time } \\
\text { to have better chances to develop my career } \\
\text { within the company. }\end{array}$ & 2.48 & 1.11 & 1 & 4 & 965 \\
\hline $\begin{array}{l}\text { If I see colleagues who have forgotten their } \\
\text { safety gear, I will tell them. }\end{array}$ & 2.13 & 0.88 & 1 & 4 & 961 \\
\hline $\begin{array}{l}\text { I strive to create a good atmosphere in the team } \\
\text { and organise meet-ups or activities like } \\
\text { barbecues or parties. }\end{array}$ & 2.16 & 0.95 & 1 & 4 & 970 \\
\hline $\begin{array}{l}\text { After work, I often think about how I could } \\
\text { develop improvement proposals for work } \\
\text { processes in my area. }\end{array}$ & 2.38 & 0.99 & 1 & 4 & 965 \\
\hline $\begin{array}{l}\text { I defend my colleagues against unfair treatment, } \\
\text { even in front of the supervisor. }\end{array}$ & 1.73 & 0.70 & 1 & 4 & 970 \\
\hline $\begin{array}{l}\text { I often volunteer to help and support new } \\
\text { colleagues to get started at their job. }\end{array}$ & 1.84 & 0.72 & 1 & 4 & 971 \\
\hline $\begin{array}{l}\text { I defend my company if someone from my } \\
\text { circle of friends criticises it. }\end{array}$ & 1.81 & 0.83 & 1 & 4 & 970 \\
\hline
\end{tabular}

Data source: Kraywdzinski and Mäblmeyer (2015) 